Article

\title{
Temporal Change of Soil Carbon on a Long-Term Experimental Site with Variable Crop Rotations and Tillage Systems
}

\author{
Ahmed Laamrani ${ }^{1,2,3,4, *}$, Paul R. Voroney ${ }^{2}$, Aaron A. Berg ${ }^{3}{ }^{-}$, Adam W. Gillespie ${ }^{2}$, \\ Michael March ${ }^{3}$, Bill Deen ${ }^{4}$ and Ralph C. Martin ${ }^{4}$ \\ 1 Center for Remote Sensing Applications (CRSA), Mohammed VI Polytechnic University (UM6P), \\ Ben Guerir 43150, Morocco \\ 2 School of Environmental Sciences, University of Guelph, Guelph, ON N1G 2W1, Canada; \\ pvoroney@uoguelph.ca (P.R.V.); agilles@uoguelph.ca (A.W.G.) \\ 3 Department of Geography, Environment \& Geomatics, University of Guelph, Guelph, ON N1G 2W1, \\ Canada; aberg@uoguelph.ca (A.A.B.); mmarch@uoguelph.ca (M.M.) \\ 4 Department of Plant Agriculture, University of Guelph, Guelph, ON N1G 2W1, Canada; \\ bdeen@uoguelph.ca (B.D.); rcmartin@uoguelph.ca (R.C.M.) \\ * Correspondence: alaamran@uoguelph.ca; Tel.: +212-662099050
}

Received: 4 May 2020; Accepted: 4 June 2020; Published: 12 June 2020

\begin{abstract}
The impacts of tillage practices and crop rotations are fundamental factors influencing changes in the soil carbon, and thus the sustainability of agricultural systems. The objective of this study was to compare soil carbon status and temporal changes in topsoil from different 4 year rotations and tillage treatments (i.e., no-till and conventional tillage). Rotation systems were primarily corn and soy-based and included cereal and alfalfa phases along with red clover cover crops. In 2018, soil samples were collected from a silty-loam topsoil $(0-15 \mathrm{~cm})$ from the 36 year long-term experiment site in southern Ontario, Canada. Total carbon (TC) contents of each sample were determined in the laboratory using combustion methods and comparisons were made between treatments using current and archived samples (i.e., 20 year and 9 year change, respectively) for selected crop rotations. Overall, TC concentrations were significantly higher for no-till compared with conventional tillage practices, regardless of the crop rotations employed. With regard to crop rotation, the highest TC concentrations were recorded in corn-corn-oats-barley (CCOB) rotations with red clover cover crop in both cereal phases. TC contents were, in descending order, found in corn-corn-alfalfa-alfalfa (CCAA), corn-corn-soybean-winter wheat (CCSW) with 1 year of seeded red clover, and corn-corn-corn-corn (CCCC). The lowest TC concentrations were observed in the corn-corn-soybean-soybean (CCSS) and corn-corn-oats-barley (CCOB) rotations without use of cover crops, and corn-corn-soybean-winter wheat (CCSW). We found that (i) crop rotation varieties that include two consecutive years of soybean had consistently lower TC concentrations compared with the remaining rotations; (ii) TC for all the investigated plots (no-till and/or tilled) increased over the 9 year and 20 year period; (iii) the no-tilled CCOB rotation with 2 years of cover crop showed the highest increase of TC content over the 20 year change period time; and (iv) interestingly, the no-till continuous corn (CCCC) rotation had higher TC than the soybean-soybean-corn-corn (SSCC) and corn-corn-soybean-winter wheat (CCSW). We concluded that conservation tillage (i.e., no-till) and incorporation of a cover crop into crop rotations had a positive effect in the accumulation of TC topsoil concentrations and could be suitable management practices to promote soil fertility and sustainability in our agricultural soils.
\end{abstract}

Keywords: agricultural soils; soil organic carbon (SOC); total carbon (TC); cropping systems; tillage systems; SOC; TC change; long-term experimental site 


\section{Introduction}

Soil holds the largest pool of terrestrial carbon (C), exceeding the combined $C$ found in the atmosphere and in vegetation [1-3]. Agricultural soils occupy $35 \%$ of the global land surface area $[4,5]$ and encompass $12 \%$ of the global soil carbon stocks [6]. Changes in cropland soil carbon stocks are regulated by complex interactions between the local soil environmental conditions and climate, as well as by agricultural management practices [7]. It is widely recognized that current and past agricultural management practices have influenced soil carbon levels and dynamics, which in turn affect soil quality and health, crop yield potentials, and atmospheric $\mathrm{CO}_{2}$ concentrations [8-10]. Numerous researchers have demonstrated that management practices such as manure application, conservation tillage, cover cropping, and residue retention can increase soil carbon stocks on agricultural lands [11]. The importance of the cropland management practices and their contributions to greenhouse gas (GHG) reductions has been reinforced by the 2015 Paris Agreement of the United Nations Framework Convention on Climate Change (UNFCCC). Therefore, the adoption of soil carbon augmentation practices coupled with monitoring is important for understanding atmospheric $\mathrm{CO}_{2}$ mitigation strategies (i.e., soil carbon sequestration) and soil conservation. In this context, soil and cropping management practices offer a powerful tool for potential climate change mitigation through soil organic carbon sequestration [12,13]. These practices include diversified crop rotations, cover cropping, residue retention, and reduced or no-tillage $[12,13]$. For example, agricultural management systems that incorporate winter wheat (Triticum aestivum), barley (Hordeum vulgare L.), oats (Avena sativa L.), alfalfa (Medicago sativa L.), and/or red clover (Trifolium pretense L.) cover crops in the rotation lead to an increase of topsoil carbon concentrations with time compared with monoculture corn (Zea mays), monoculture soybean (Glycine max), or soybean-corn [9,14-16]. Managing the soil carbon resource appropriately in agricultural management systems can provide a wide range of environmental benefits such as water quality improvement and erosion control. However, soil carbon responds slowly to changes in agricultural management and most changes require many years to be detected [17]. Therefore, studies on the effects of agricultural management practices (i.e., cropping and tillage systems) on soil carbon levels are typically assessed from long-term field experiments (e.g., [14,18]). These long-term field experiments offer long-term studies of soil carbon changes under the most widely cultivated crops and cropping systems [19].

In 2015, about $7 \%$ of the total land area in Canada was under agriculture with two-thirds used for crops and improved pasture. The province of Ontario, with 3.7 million hectares of total cropland, accounts for $10 \%$ of Canada's agricultural land $[20,21]$. Over three million hectares are located in southwestern Ontario [19] and, in this region, soybean, corn, and winter wheat are the main crops by planted area. In Canada, data obtained from different long-term studies have provided valuable contributions to understanding of the linkages between soil carbon stocks in topsoil (i.e., $0-15 \mathrm{~cm}$ layer) and management practices [22-30]. In addition, these studies contribute to our understanding of how different agricultural management practices (i.e., cover crops and tillage) can interact in driving changes in soil carbon [19]. Finally, as soil carbon is often used as a proxy for soil health, these long-term studies offer highly relevant datasets that can be used to infer the effects of management practices on sustainable agriculture goals.

There is a need to provide continuous updated estimates and uncertainties of soil carbon concentrations in agricultural soils and changes over time within these long-term field experiments. However, to our knowledge, few studies have been carried out in southern Ontario for the length of time greater than 35 years (i.e., [19]). To this end, the crop rotation experiment established at the Elora Research Station in 1982 presents a unique opportunity to investigate the link between long-term agricultural activities (tillage systems and/or crop rotation) on soil carbon changes over time. This site has a fully replicated and blocked study that compares corn, soybean, and wheat-containing rotations, nested with tillage and cover crop treatments. The objective of this research was to examine the effects of long-term agricultural management practices (tillage and cropping system) on the temporal soil carbon changes after 36 years. Here, we identify the specific tillage and cropping practices and/or their 
interactions that promote soil carbon accumulation over the long-term. We hypothesize that soil carbon levels will be higher: (i) in diversified crop rotations (including cereals or alfalfa) contrasted with monoculture or biphase corn and soy; (ii) under no-till contrasted with moldboard plow; and (iii) with red clover cover crops undersown to winter wheat, oat, and barley contrasted with no cover crops. By revealing which cropping and tillage practices and/or their interactions best maintain or improve carbon soil accumulation, farmers will have the opportunity to plan their management accordingly.

\section{Materials and Methods}

\subsection{Study Site Description}

The study site is located at the University of Guelph's Elora Research Station in Southern Ontario, Canada $\left(43^{\circ} 38^{\prime} 25.74^{\prime \prime} \mathrm{N} ; 80^{\circ} 24^{\prime} 36.64^{\prime \prime} \mathrm{W}\right.$; Figure 1). The soils at the field site are classified according to the Canadian System of Soil Classification [31] as Grey Brown Luvisols (Albic Luvisol, FAO system) and a member of the Woolwich silt loam series [32]. The soil is characterized by $15 \%$ clay, $36 \%$ sand, and $49 \%$ silt, and a pH of 7.3 in 2015 [14]. The field has a gentle slope ranging from 0 to 2.6 degrees and elevation ranges between 370 and $373 \mathrm{~m}$ above sea level. The climate is characterized by long, moderate winters (November-April) and warm, humid summers (i.e., humid continental climate). The mean annual temperature is $6.3{ }^{\circ} \mathrm{C}$ and total annual precipitation is $937 \mathrm{~mm}$. About one-third of the annual precipitation falls during the peak vegetative growth period, between early May and August. December, January, and February are the coldest months with a mean temperature of $-6.6^{\circ} \mathrm{C}$, while June, July, and August are the warmest months with a mean temperature of $18.5^{\circ} \mathrm{C}$ (Environment Canada [33]; the 30 year average data from Fergus Shand Dam weather station, which is located $12 \mathrm{~km}$ NE of the study site). A more detailed description of the experimental study site is provided in previous studies [14,27,34-36]).

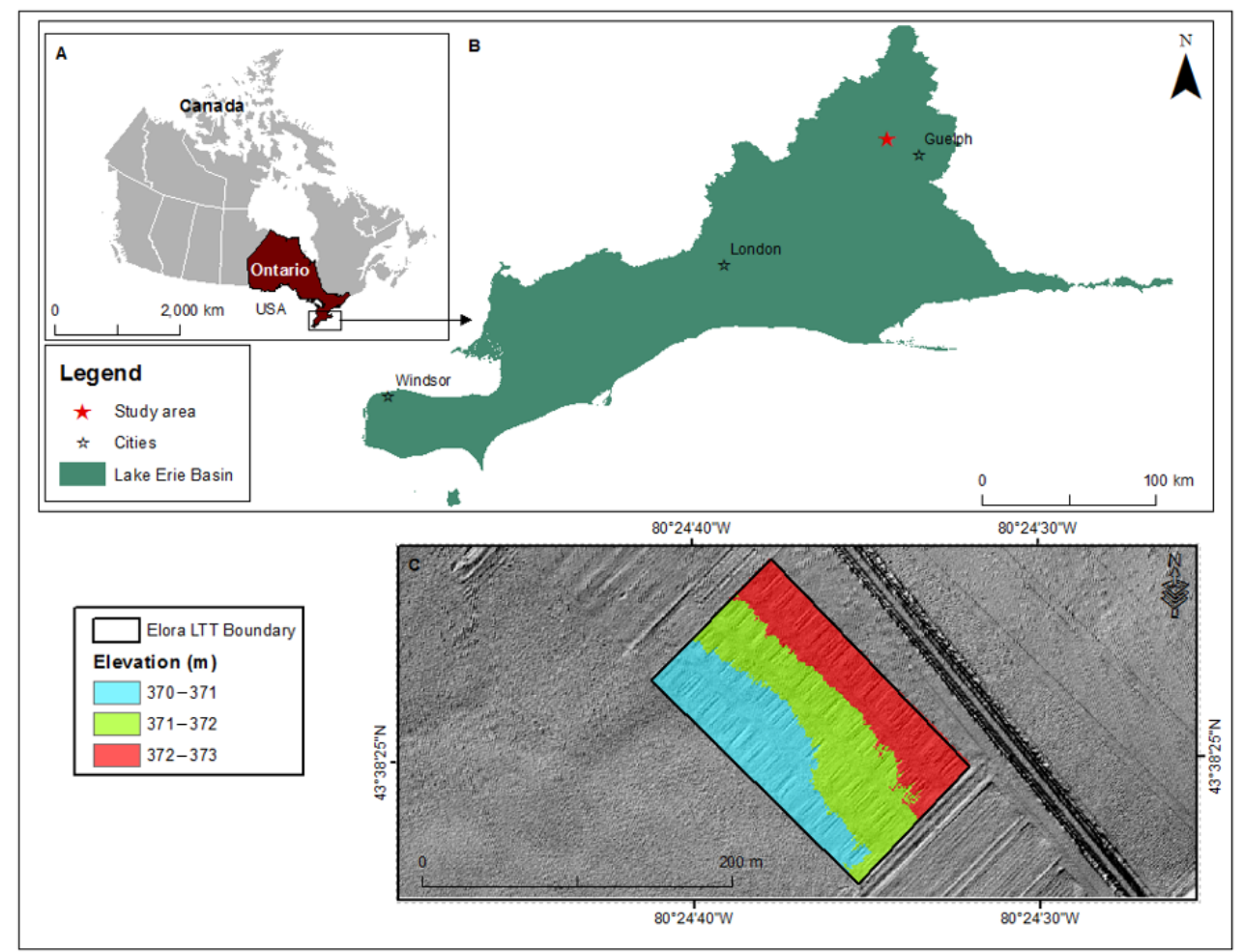

Figure 1. Location of the study site in southwestern Ontario (A) within the Lake Erie Basin (B). Topography of the long-term crop rotation/tillage site (C). 


\subsection{Experimental Setup and Design}

Historically, the experimental site was planted to continuous corn from 1967 to 1980. The crop rotation/tillage experimental site was initiated in 1980; the two first years (1980-1982) of the trial were used as set up years [34] and not included in this analysis. The 36 year experiment at the site consists of 14 cropping treatments and two types of tillage: no-till and conventional tillage [27]. The experimental site was set out in a randomized block split-plot design with four blocks (B1 to B4; Figure 2). Each block encompasses 28 plots (i.e., 14 crops $\times 2$ tillage treatments; Figure 2). Each plot covers an area of $119 \mathrm{~m}^{2}$ $(7 \mathrm{~m} \times 17 \mathrm{~m})$ for a total field area of $1.3 \mathrm{ha}$. The crops were grown in a 4 year rotation that were randomly assigned to the different plots (Figure 2).

Table 1. Description of codes used to represent crop rotation type for the study and descriptive statistics of total carbon (TC) data collected in 2018.

\begin{tabular}{|c|c|c|c|c|c|c|c|}
\hline Rotation Type & $\begin{array}{l}\text { Rotation } \\
\text { Code }\end{array}$ & $n$ & \multicolumn{4}{|c|}{ Total Carbon (\%) } & $\begin{array}{c}\text { Significant } \\
\text { Difference }^{\dagger}\end{array}$ \\
\hline Continuous corn & CCCC & 8 & 2.11 & 3.38 & 2.66 & 0.43 & $\mathrm{ad}$ \\
\hline Continuous alfalfa & AAAA & 8 & 2.42 & 3.25 & 2.81 & 0.25 & $\mathrm{~d}$ \\
\hline Corn-corn-oats-barley & $\mathrm{CCOB}$ & 8 & 2.09 & 2.91 & 2.63 & 0.27 & ad \\
\hline Oats-barley-corn-corn & $\mathrm{CCOB}$ & 8 & 2.06 & 2.67 & 2.44 & 0.25 & $a b$ \\
\hline Corn-corn-soybeans-soybeans & CCSS & 8 & 1.74 & 2.73 & 2.19 & 0.36 & a \\
\hline Soybeans-soybeans-corn-corn & SSCC & 8 & 1.78 & 2.93 & 2.40 & 0.45 & ac \\
\hline Corn-corn-soybeans-winter wheat & CCSW & 8 & 2.45 & 2.98 & 2.67 & 0.20 & ac \\
\hline Soybeans-winter wheat-corn-corn & SWCC & 8 & 2.34 & 3.10 & 2.73 & 0.26 & ad \\
\hline Corn-corn-soybeans-winter-wheat (RC) & $\mathrm{CCSW}^{*}$ & 8 & 1.83 & 2.97 & 2.51 & 0.41 & $\mathrm{ad}$ \\
\hline
\end{tabular}

*: Red clover was seeded as a cover crop (i.e., 1 year out of 4 year rotation) in winter wheat. ${ }^{* *}$ : Red clover was seeded as a cover crop (i.e., 2 year out of 4 year rotation) in both winter wheat and barley. ${ }^{\dagger}$ : Different lower-case letters designate statistically significant difference $(p<0.05)$ between the treatments, according to pairwise Tukey test.

Rotation systems were primarily corn and soybean-based and were also contrasted to cereal (i.e., winter wheat, oats, barley) and alfalfa phases (Figure 2). In the cover crop treatments, red clover was undersown to winter wheat, oats, and barley. Continuous alfalfa is also present in this study. The fourteen rotations and their respective codes used, hereafter, are shown in Table 1. Conventional tillage consisted of moldboard plowing to $15-20 \mathrm{~cm}$ depth in fall followed by secondary tillage with a field cultivator to $10 \mathrm{~cm}$ depth and packer in the following spring [27]. From 1982 to 2001, conservation tillage consisted of a 15-20 cm fall chisel plowing. Commencing in 2002, the conservation tillage system was converted to no-till [34]. The no-till treatment involved spraying with glyphosate herbicide prior to planting with a direct seed drill. The remaining corn residue (i.e., stover) was retained in the plots, chopped, and returned to soil during tillage, whereas cereal (i.e., winter wheat, oats, barley) straw residue was not retained. Alfalfa crops were harvested and baled. Fertilizer applications are detailed in Congreves et al. [14]. To summarize, corn received $157 \mathrm{~kg} / \mathrm{ha}$ at planting (0-20-20), with a sidedress injection of $420 \mathrm{~L} / \mathrm{ha}$ of urea ammonium nitrate. Thus, 160 to $170 \mathrm{~kg} \mathrm{~N} / \mathrm{ha}, 23-32 \mathrm{~kg} \mathrm{P} / \mathrm{ha}$, and 50-90 kg $\mathrm{K} / \mathrm{ha}$ fertilizer were applied annually for corn; no fertilizer was applied to soybean; whereas 300 and $200 \mathrm{~kg} / \mathrm{ha}$ of 34-0-0 was broadcast for winter wheat and barley, respectively. 


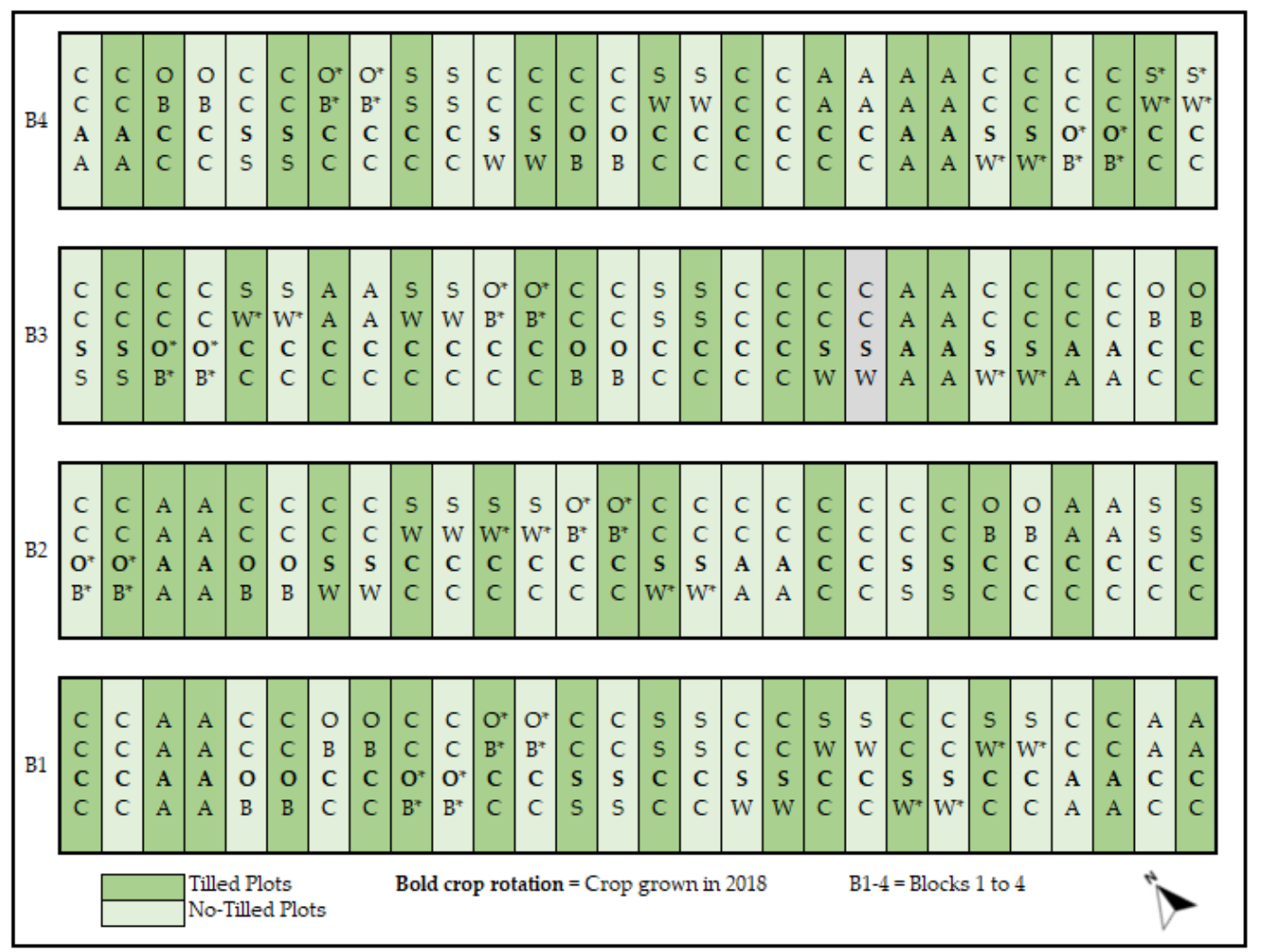

Figure 2. Field study layout and location of the plots with their respective descriptive crop rotation type cited in Table 1. Soil samples were collected from the center of each plot. For the purpose of illustration, the scale was not respected. C-corn (Zea mays); S-soybean (Glycine max); W-winter wheat (Triticum aestivum); B-barley (Hordeum vulgare L.); O-oats (Avena sativa L.); A-alfalfa (Medicago sativa L.);

*-red clover (Trifolium pretense L.) cover crop after cereal harvest.

\subsection{Soil Sampling and Total Carbon (TC) Measurements}

During Fall 2018, soil samples were collected from each plot after crop harvest. We established a 1 $\mathrm{m}$ equilateral triangle configuration at the center of each plot and collected three samples from the topsoil $(0-15 \mathrm{~cm})$ using a soil auger. Soil samples were air-dried, crop roots and residues removed, ground to pass through a $200 \mu \mathrm{m}$ sieve, and analyzed for total carbon (referred to henceforward as TC) via combustion in a Leco CR-12 Carbon analyzer (Leco Corporation, St. Joseph, MI, USA) [37]. In total, 336 samples (112 plots $\times 3$ soil samples) were analyzed for total carbon. The three sample measurements of TC for each plot were averaged to provide a mean TC concentration used in subsequent data analyses. It is important to mention that soil inorganic carbon (IC; i.e., carbonates) was not removed in laboratory for the 336 samples. However, previous analysis conducted in the University of Guelph samples from the same 112 plots have found an average of $0.8 \%$ IC of the TC \% over the investigated plots.

\subsection{Comparisons Over Time: 1998 to 2018, and 2009 to 2018}

For this study, we also compared our TC measurements collected in 2018 (Table 1) to those obtained previously in 1998 (i.e., 21 year period change) and in 2009 (i.e., 10 year period change). The 1998 and 2009 datasets belong to a large database on the Elora long-term field experiment. These, two legacy datasets cover only selected plots and/or treatments and are treated separately in comparison with 2018 data. For the 1998 to 2018 dataset (unpublished), the CCCC, CCOB**, SSCC, SWCC, and SWCC* rotations were compared for tilled and no-tilled. For the 2009 to 2018 dataset (unpublished), the CCAA, CCSW $^{*}$, CCCC, CCSW, and CCSS rotations were compared for tilled only. Furthermore, the 2009 carbon dataset TC data were not directly available; for the purpose of comparison, the 2009 soil organic carbon content was converted to TC content using the inorganic estimate fraction determined above. 


\subsection{Statistical Analyses}

In a first stage of analysis, the effects of the tillage and the 14 crop rotation practices and their interaction on TC (the response variable) over time were tested using an analysis of variance (ANOVA). This analysis showed that crop rotations with the same crop sequence, but in different phases were not statistically different, and were thus combined by rotation treatments. For the second analysis, for instance, tilled CCOB and OBCC do not differ significantly in terms of TC content. Therefore, to provide more meaningful comparisons of management/tillage effects on TC concentrations, those cropping systems that are the same (i.e., $\mathrm{CCOB} v s \mathrm{OBCC}$ ) were combined in one rotation type (i.e., $\mathrm{CCOB}$ ) for further analyses. In addition, continuous alfalfa (AAAA) was not included in further analysis as it was never no-tilled and does not offer a reasonable comparison (i.e., for statistical balanced comparison of till vs. no-till).

In the second stage, two-way ANOVA were performed on the reduced dataset of seven rotation treatments to compare tillage factors (tilled vs. no-tilled), the combined crop rotations, and their interaction on TC response. This was followed by Tukey honest significant difference (HSD) tests to compare means when a significant ANOVA main effect or interaction was encountered for a given variable and to evaluate if the investigated treatments significantly differed. Statistical significance of the selected predictor variables and the whole model was evaluated and declared significant at a level of $\alpha=0.05$ (i.e., $p$-value $\leq 0.05$ ). Assumptions regarding the lack of multicollinearity (variance inflation factors), normality of the data (Shapiro-Wilk test), and equal error variance (homoscedasticity, Levene's test) of the linear models were satisfied. Statistical analyses were performed in $\mathrm{R}$ (Version 3.6.0 for Windows; R Development Core Team [38]) using the car, multcompview and lsmeans packages.

\section{Results}

Table 1 illustrates the TC content from each of the 14 crop rotation plots (i.e., both no-tilled and tilled) including continuous alfalfa (AAAA) plots. Overall, the highest TC contents were in plots with alfalfa (i.e., AACC, CCAA, and AAAA), whereas rotations with two successive years of soybean had the lowest TC concentrations. As mentioned above, when the same rotation system was used (i.e., CCAA vs. AACC, only with a different order of the planted crops), the different phases were not significantly different at $p \leq 0.05$, regardless of the tillage system.

\subsection{Effects of Tillage Practice and Cropping System on Soil Total Carbon Percent After 36 Years}

Table 2 shows that the TC concentrations of the seven selected rotation systems ranged between $1.82 \%$ and $3.39 \%$, which is typical for agricultural soils in southern Ontario. ANOVA results found that both tillage practice and cropping rotation system and selected interactions significantly influenced the TC concentrations $(p<0.001$; Figure 3$)$. TC concentrations in the tilled and no-tilled plot were significantly different $(p<0.001)$, with a mean of $2.51 \%$ and $2.73 \%$, respectively. Regardless of tillage system, the highest TC concentrations were recorded in the $\mathrm{CCOB}^{* *}$ rotation planted with a red clover cover crop in both cereal phases, followed by CCAA, CCSW* with red clover in the cereal phase, and CCCC rotations with mean concentrations of $3.01 \%, 2.94 \%, 2.76 \%$, and $2.75 \%$, respectively (Table 2). The lowest TC concentrations were recorded in the tilled plots, with CCSS followed by CCSW and CCOB rotations with mean concentrations of $1.82 \%, 1.87 \%$, and $1.99 \%$, respectively (Table 2). Under the same crop rotation type (i.e., CCCC), the mean TC concentrations were consistently higher in no-till plot compared with tilled plot (Table 2). Regardless of tillage system, the crop rotations that included two years of soybean had the lowest TC concentrations.

A significant influence of the two-way interactions between rotation and tillage treatments was only found in selected combinations. The no-till/CCOB** rotation with a red clover was the most significantly different (i.e., five out of nine) compared with other interactions. For instance, interactions between no-till/CCOB ${ }^{* *}$ were significantly different from the respective interactions till/CCSS $(p<0.001)$, till/CCOB $(p<0.05)$, no-till/CCSS $(p<0.05)$, till/CCSW $(p<0.05)$, and till/CCSW* 
$(p<0.05)$. The other four significant interactions are between till/CCSS and no-till/CCAA $(p<0.01)$; till/CCSS and no-till/CCSW* $(p<0.05)$; no-till/CCSS and no-till/CCAA $(p<0.05)$; and till/CCOB and no-till/CAAA $(p<0.05)$.

Table 2. Summary statistics for the measured 2018 total carbon percentage within the seven selected treatments for the till and no-till treatments. Mean topsoil TC concentrations are ranked from the highest $\left(\right.$ top $\left.=\mathrm{CCOB}^{* *}\right)$ to the lowest $($ bottom $=\mathrm{CCSS})$.

\begin{tabular}{ccccccccc}
\hline \multirow{2}{*}{ Rotation $^{+}$} & \multicolumn{9}{c}{ Till } & \multicolumn{5}{c}{ No-Till } \\
\cline { 2 - 10 } & Min & Max & Mean & SE & Min & Max & Mean & SE \\
\hline CCOB $^{* *}$ & 2.39 & 2.90 & 2.69 & 0.08 & 2.62 & 3.39 & 3.01 & 0.12 \\
CCAA $^{2}$ & 2.36 & 2.87 & 2.64 & 0.08 & 2.50 & 3.37 & 2.94 & 0.13 \\
CSW $^{*}$ & 2.07 & 2.77 & 2.45 & 0.12 & 2.56 & 2.94 & 2.76 & 0.06 \\
CCCC & 2.11 & 2.73 & 2.43 & 0.14 & 2.37 & 2.96 & 2.75 & 0.13 \\
CCSW & 1.87 & 2.69 & 2.42 & 0.11 & 2.08 & 3.05 & 2.70 & 0.14 \\
CCOB & 1.99 & 2.73 & 2.38 & 0.12 & 2.28 & 2.80 & 2.60 & 0.09 \\
CCSS & 1.82 & 2.52 & 2.17 & 0.11 & 1.86 & 2.78 & 2.39 & 0.15
\end{tabular}

${ }^{+}$: Rotation with the same crops in different phases in Table 1 that are not significantly different were combined (i.e., CCAA and AACC combined in CCAA). *: Red clover was seeded as a cover crop (i.e., 1 year out of 4 year rotation) in winter wheat. **: Red clover was seeded as a cover crop (i.e., 2 year out of 4 year rotation) in both winter wheat and barley. $\mathrm{SE}=$ Standard error of the mean.

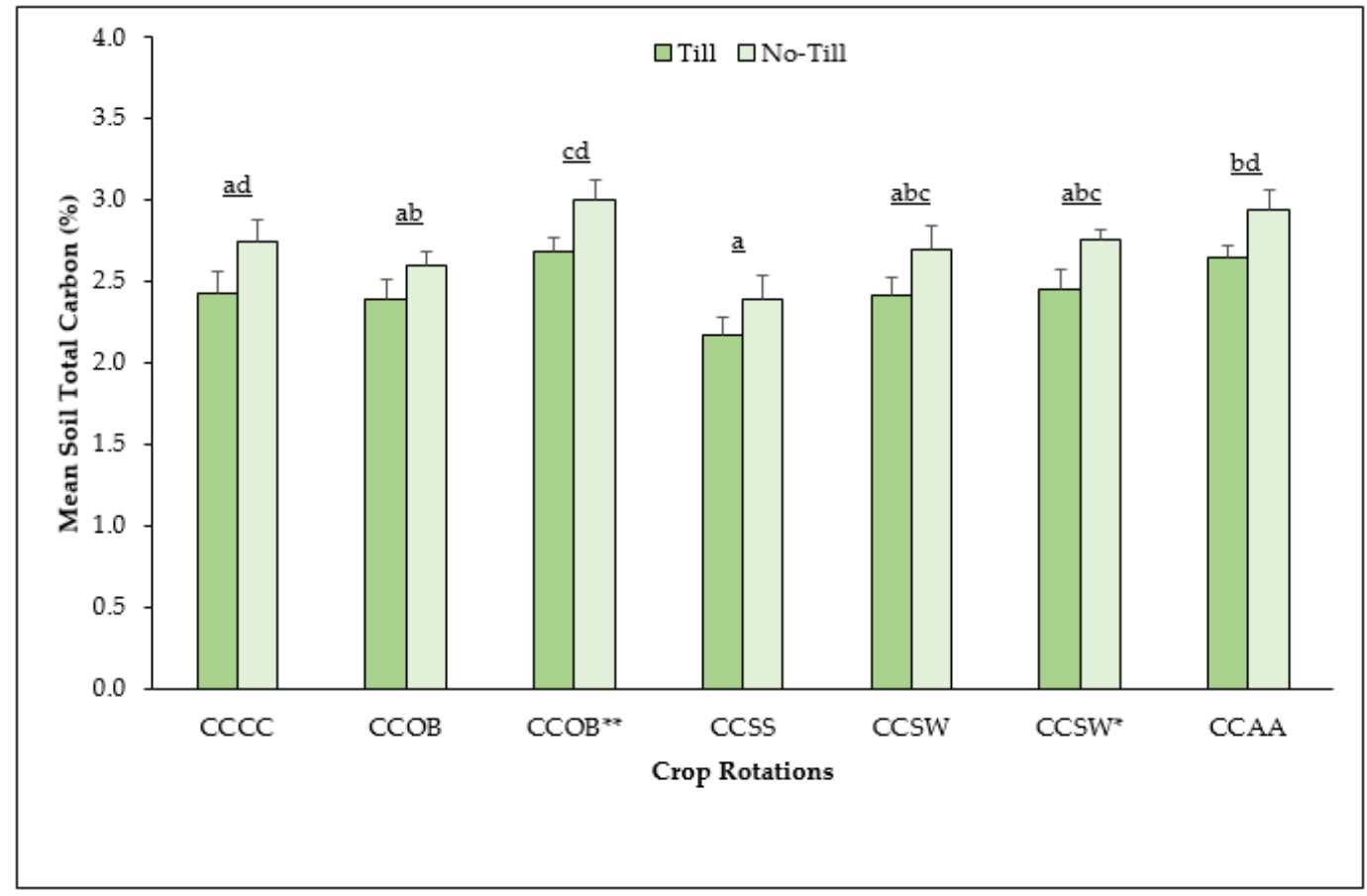

Figure 3. Topsoil total carbon concentrations in the seven cropping systems for tilled and no-tilled plots of the 2018 dataset. Different lower-case letters designate statistically significant difference $(p \leq$ 0.05 ) between the treatments, according to pairwise Tukey tests. Error bars indicate standard error (SE) of the mean. Asterisk refer to red clover undersown to cereals, as explained in Table 1.

\subsection{Comparisons Over Time: 1998 to 2018, and 2009 to 2018}

Total soil carbon comparisons between 1998 and 2018 are treated separately from the 2009 to 2018 comparison because of different historical sample sets. Figure 4 shows the five selected crop rotations for both tilled and no-tilled plots for which TC data are available for 1998 and the estimated 20 year period change (1998-2018). Overall, TC for all the plots (tilled or no-tilled) increased over the 20 year period. The no-tilled $\mathrm{CCOB}^{* *}$ rotation with 2 years in cover crop shows the highest increase 
of TC content over the change period; thus, both cover crop and no-till had a positive effect in the accumulation of TC. The no-till and till continuous corn had the second highest TC content, while the SSCC rotation displayed the lowest increase for both tilled and no-tilled plots. Figure 4 also show a consistent noticeable tillage effect among the investigated plots when 2018 topsoil TC concentrations are compared to those measured in 1998. Given that the conversion to no-till did not occur until 2002, it is not surprising that the no-tilled plots had higher amounts of change.

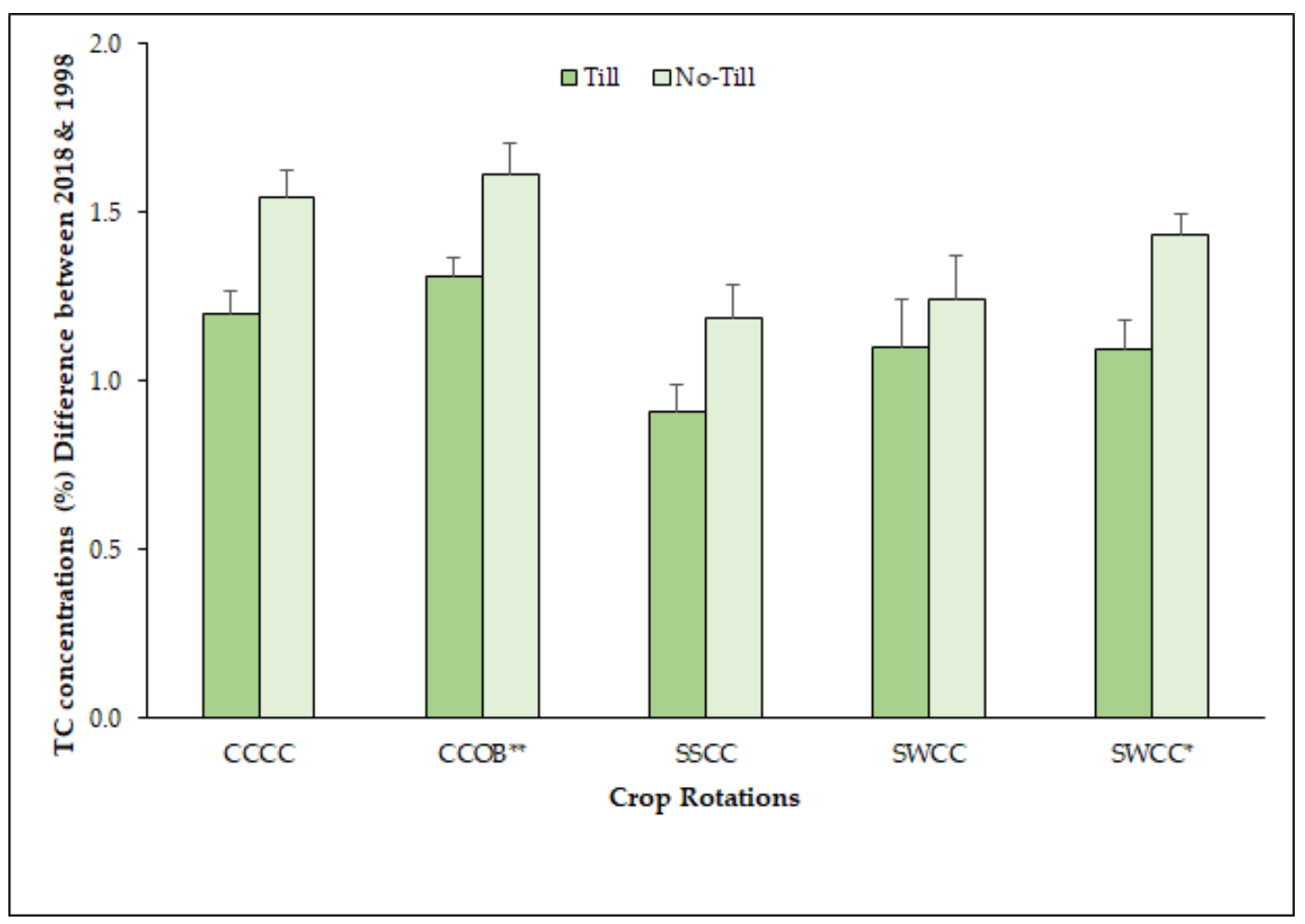

Figure 4. The estimated change in topsoil total carbon (TC) content in five crop rotations for both tilled and no-tilled plots for 1998 to 2018 period. The 1998 TC data are available only for the displayed five plotted combinations of rotations. Error bars indicate SE of the mean. Asterisks refer to red clover undersown to cereals.

Table 3 shows TC content changes over time between 2009 and 2018. Overall, the same increasing TC trend was also recorded in a dataset collected in 2009 over corn/till interaction plots. The highest changes were from about $21 \%$ for CCAA followed by CCSW* with red clover $(19 \%)$ and CCCC $(18 \%)$, whereas the lowest changes were for CCSS and CCSW with 10\% and $12 \%$. respectively.

Table 3. Shows TC content changes over time between 2009 and 2018.

\begin{tabular}{ccccc}
\hline & \multicolumn{2}{c}{ Total Carbon } & \multicolumn{2}{c}{$\Delta$ TC } \\
\cline { 2 - 5 } Rotation & $\mathbf{2 0 1 8}$ & $\mathbf{2 0 0 9}$ & \multicolumn{2}{c}{$\mathbf{2 0 1 8 - 2 0 0 9}$} \\
\cline { 2 - 5 } & $\mathbf{\%}$ & $\mathbf{\%}$ & Change \% & Relative Change \% \\
\hline CCAA & 2.64 & 2.10 & 0.54 & 21 \\
CCSW & 2.45 & 1.99 & 0.46 & 19 \\
CCCC & 2.43 & 1.99 & 0.44 & 18 \\
CCSW & 2.42 & 2.13 & 0.28 & 13 \\
CCSS & 2.17 & 1.89 & 0.28 & 13 \\
\hline
\end{tabular}

*: Red clover was seeded as a cover crop (i.e., 1 year out of 4 year rotation) in winter wheat. $\Delta$ : TC difference between 2018 and 2009. 


\section{Discussion}

In the agricultural region of southern Ontario, knowledge of the status and temporal changes of TC is crucial for monitoring soil in the context of soil health, carbon sequestration, and climate change mitigation. This study reports that all TC concentrations in topsoil responded to tillage and crop rotation treatments. In all instances, no-till plots had higher values of TC compared with moldboard tillage. This is consistent with many previous long-term studies that reported higher topsoil carbon for no-tillage compared with conventional tillage practices in eastern Canada $[14,15,18,27,39,40]$ and in Iowa, United States of America [41]. However, in this study, we found that some crop rotations and tillage interactions impact the TC change, which is in contrast with some previous studies (e.g., [15]). We were not able to identify the exact mechanism for this high impact and more research will be needed to be further explore that interaction.

The incorporation of cover crops in the cereal phase increases TC accumulation. The highest TC increases were recorded in plots where red clover cover crops were planted after winter wheat (i.e., $\mathrm{CCSW}^{*}$; 1 year out of a 4 year rotation) and after oats and barley $\left(\mathrm{CCOB}^{* *}\right.$; i.e., 2 year out of a 4 year rotation). This finding suggests that, in terms of TC accumulation, the incorporation of cereals (i.e., winter wheat, barley, oats) and a cover crop post-cereal harvest has greater impacts on TC storage than increasing the diversity of crop rotation. For instance, the incorporation of red clover into no-till $\mathrm{CCOB}^{* *}$ rotation plots increased the TC concentration by approximatively $11 \%$ (i.e., $\mathrm{CCOB}^{* *}$ vs. CCOB; Table 2). This finding is consistent with previous work $[14,15,30,32,42]$, which found that cropping systems that have cover crops (e.g., alfalfa or red clover) in rotations with cereals had the highest soil organic carbon compared with other diversified cropping systems without cover crops. The increase of soil carbon in rotations with red cover suggests this addition is beneficial for preserving and growing soil organic matter throughout the input of high quality residue (i.e., $\mathrm{C} / \mathrm{N}$ ratios) to the soil. Other studies have found that, in addition to increasing soil carbon, red clover may also play a crucial role in soil health. These benefits can include the increase of soil aggregation, which will reduce the susceptibility of the soil to erosion [43], enhancing soil microbial biomass and activity through addition of labile residues and nitrogen [44], and the increase of soil nitrogen supply as red clover is known to generate greater soil microbial biomass carbon and mineralizable nitrogen [45].

In contrast, our results indicated that the frequency of soybean in crop rotations decreased soil carbon compared with the remaining rotations. The lowest TC contents were in corn-cornsoybean-soybean-corn-corn (CCSS), followed by corn-corn-soybean-winter wheat (CCSW), regardless of the tillage system. This was expected given that soybean returns little biomass to the soil [46]. This may suggest that rotations producing low residue crops such as soybean may not be beneficial for preserving and/or increasing soil carbon. Continuous corn (CCCC), however, had a higher TC content than CCSS and CCSW. This finding is in contrast with a previous study by Angers [47] and Congreves et al. [14], which found continuous corn crop rotation decreased soil carbon. In this system, it appears that the high biomass return of continuous corn is more influential on TC than the effects of low biomass return from soybean and cereals that have had straw removed. It is important to mention that, although this study demonstrated that CCCC increases TC (keeping in mind that corn stover was retained), we do not recommend such cropping system, as there are disease, pest, and erosion risks associated with mono-cropping [46].

Similar to several other studies $[18,48-53]$, the results here were reported as TC content (i.e., $\mathrm{g} \mathrm{C} / \mathrm{kg}$ soil) from samples taken from $0-15 \mathrm{~cm}$ depth rather than as carbon stocks. Soil bulk density (BD) is required to translate TC concentrations into carbon stocks [54], which was not available for the 1998 and 2009 sampling times. This study aligns with Lee et al. 2009 [55], who found that soil carbon concentration data were a better measure than soil carbon stock estimates. Furthermore, we anticipate that the trends in the change of TC content through time would have been similar when considering only the carbon stocks in the equivalent depth.

In addition to the effect of tillage and crop rotation, other factors such as topography and organic carbon inputs (i.e., manure, compost) are known to influence TC accumulation in the agricultural soils 
in southern Ontario. A box plot analysis (Figure not shown here) of TC over the four studied blocks (i.e., B1-B4 in Figure 2) shows that there was no significant difference in TC datasets between the four blocks, suggesting that there is no significant effect of topography (i.e., by surface run-off/leaching) at the experimental site on TC concentrations.

The combination of TC field measurements with long-term tillage and crop rotation information has improved our understanding of how tillage and crop rotations influence TC status in the topsoil and can constitute a significant first step in predicting and mapping soil across the landscape. The policy implications of this study are to develop incentives for appropriate and cost-effective agricultural management activities that enhance soil carbon content, and ultimately crop productivity. These results can provide managers and researchers with a more complete understanding of tillage and rotation impacts on TC storage and allow for a benchmark for further investigations for monitoring the impact of management practices on TC at the surface. Furthermore, the data will support an interactive assessment tool that accounts for the impact of agricultural land management practices on soil carbon and functions. Finally, we believe that the results from this study can contribute to improve modelling efforts to describe soil carbon dynamics (i.e., [16]) in cropping systems and to estimate regional and national soil carbon balances for agricultural soils in Canada and other similar climate zones in which wheat, barley, corn, or soybean can grow in crop rotation.

\section{Conclusions}

In this study, the effects of 36 year long-term tillage and crop rotation practices and their interaction on the total carbon concentration in the surface layer were tested. We found that the combination of no-till and some specific cropping systems practices increased TC concentrations in the topsoil. The highest TC concentrations were recorded in corn-corn-oats-barley (CCOB) rotations with a red clover cover crop in both cereal phases combined with no-till, whereas the lowest TC concentrations were observed in the corn-corn-soybean-soybean (CCSS) and corn-corn-oats-barley (CCOB) rotations without integrated cover crops, suggesting that the incorporation of cover crop is very important for TC storage in the topsoil. On the basis of our findings, we concluded that conservation tillage (i.e., less tillage, no-till, or reduced till) can increase the soil carbon concentration as do rotations that include more than 1 year cover crops (preferably 2 year out of a 4 year rotation) or perennial crops and, therefore, could be suitable management practices to promote soil quality, health, and sustainability, and to mitigate global warming by enhancing carbon storage.

Author Contributions: A.L., P.R.V., A.A.B., A.W.G., M.M., B.D., and R.C.M., the authors of this paper have contributed substantially to the work reported here, and to the original draft preparation of the manuscript. Conceptualization of the experimental site sampling + methodology + formal analysis, A.L., P.R.V., and B.D.; investigation and resources, A.L., P.R.V., M.M., A.A.B., A.W.G., and R.C.M.; Field data collection, A.L., and M.M.; data curation, A.L., P.R.V., and B.D.; writing—original draft preparation, A.L.; writing - review and editing, P.R.V., A.A.B., A.W.G., B.D., and R.C.M., supervision, project administration, and funding acquisition, R.C.M. All authors have read and agreed to the published version of the manuscript.

Funding: The authors gratefully acknowledge funding from Agricultural Greenhouse Gases Program-Agriculture and Agri-Food Canada (AGGP-015 awards to Dr. Ralph Martin), the Christian Farmers Federation of Ontario, and the Canada First Excellence Research Fund: Food from Thought.

Acknowledgments: The authors thank the University of Guelph for access to their Elora Research Station land for this study and to the long-term experimental site and the related database, and Line Blackburn who assisted with fieldwork, soil samples acquisition, processing, and analyses of soil carbon. We also thank the editor and three anonymous reviewers for their helpful comments that greatly improved earlier versions of the manuscript.

Conflicts of Interest: The authors declare no conflict of interest.

\section{References}

1. Lal, R. Soil carbon sequestration impacts on global climate change and food security. Science 2004, 304, 1623-1627. [CrossRef] 
2. Parry, M.L.; Canziani, O.F.; Palutikof, J.P.; van der Linden, P.J.; Hanson, C.E. Climate Change 2007-Impacts, Adaptation and Vulnerability: Working Group II Contribution to the Fourth Assessment Report of the IPCC; Cambridge University Press: Cambridge, UK, 2007.

3. Scharlemann, J.P.; Tanner, E.V.; Hiederer, R.; Kapos, V. Global soil carbon: Understanding and managing the largest terrestrial carbon pool. Carbon Manag. 2014, 5, 81-91. [CrossRef]

4. Betts, R.A.; Falloon, P.D.; Goldewijk, K.K.; Ramankutty, N. Biogeophysical effects of land use on climate: Model simulations of radiative forcing and large-scale temperature change Agric. For. Meteorol. 2007, 142, 216-233. [CrossRef]

5. Schlesinger, W.; Bernhardt, E.S. Biogeochemistry: An Analysis of Global Change, 3rd ed.; Elsevier: Oxford, UK, 2013.

6. Zomer, R.J.; Bossio, D.A.; Sommer, R.; Verchot, L.V. Global sequestration potential of increased organic carbon in cropland soils. Sci. Rep. 2017, 7, 15554. [CrossRef] [PubMed]

7. Weil, R.R.; Brady, N.C. The Nature and Properties of Soils (Fifteenth Edition, Global Edition); Pearson Prentice Hall: Harlow, UK; London, UK; New York, NY, USA, 2017.

8. Kätterer, T.; Andersson, L.; Andrén, O.; Persson, J. Long-term impact of chronosequential land use change on soil carbon stocks on a Swedish farm. Nutr. Cycl. Agroecosyst. 2008, 81, 145-155. [CrossRef]

9. Söderström, B.; Hedlund, K.; Jackson, L.E.; Kätterer, T.; Lugato, E.; Thomsen, I.K.; Jørgensen, H.B. What are the effects of agricultural management on soil organic carbon (SOC) stocks? Environ. Evid. 2014, 3, 2. [CrossRef]

10. Sanden, T.; Spiegel, H.; Stuger, H.-P.; Schlatter, N.; Haslmayr, H.-P.; Zavattaro, L.; Grignani, C.; Bechini, L.; Dhose, T.; Molendijk, L.; et al. European long-term field experiments: Knowledge gained about alternative management practices. Soil Use Manag. 2018, 34, 167-176. [CrossRef]

11. Paustian, K.; Lehmann, J.; Ogle, S.; Reay, D.G.; Robertson, P.; Smith, P. Climate-smart soils. Nature 2016, 532, 49-57. [CrossRef]

12. Lal, R.; Delgado, J.; Groffman, P.; Millar, N.; Dell, C.; Rotz, A. Management to mitigate and adapt to climate change. J. Soil Water Conserv. 2011, 66, 276-285. [CrossRef]

13. González-Sánchez, E.; Ordóñez-Fernández, R.; Carbonell-Bojollo, R.; Veroz-González, O.; Gil-Ribes, J. Meta-analysis on atmospheric carbon capture in Spain through the use of conservation agriculture. Soil Tillage Res. 2012, 122, 52-60.

14. Congreves, K.; Hayes, A.; Verhallen, E.; Van Eerd, L. Long-term impact of tillage and crop rotation on soil health at four temperate agroecosystems. Soil Tillage Res. 2015, 152, 17-28. [CrossRef]

15. Van Eerd, L.L.; Congreves, K.A.; Hayes, A.; Verhallen, A.; Hooker, D.C. Long-term tillage and crop rotation effects on soil quality, organic carbon, and total nitrogen. Can. J. Soil Sci. 2014, 94, 303-315. [CrossRef]

16. Álvaro-Fuentes, J.; Plaza-Bonilla, D.; Arrúe, J.L.; Lampurlanés, J.; Cnatero-Martínez, C. Soil organic carbon storage in a no-tillage chronosequence under Mediterranean conditions. Plant Soil 2014, 376, 31-41. [CrossRef]

17. Ludwig, B.; Geisseler, D.; Michel, K.; Joergensen, R.G.; Schulz, E.; Merbach, I.; Raupp, J.; Rauber, R.; Hu, K.; Niu, L.; et al. Effects of fertilization and soil management on crop yields and carbon stabilization in soils. A review. Agron. Sustain. Dev. 2011, 31,361-372. [CrossRef]

18. VandenBygaart, A.; Gregorich, E.; Angers, D. Influence of agricultural management on soil organic carbon: A compendium and assessment of Canadian studies. Can. J. Soil Sci. 2003, 83, 363-380. [CrossRef]

19. Bai, Z.; Caspari, T.; Gonzalez, M.R.; Batjes, N.H.; Mäder, P.; Bünemann, E.K.; de Goede, R.; Brussaard, L.; $\mathrm{Xu}$, M.; Ferreira, C.S.S.; et al. Effects of agricultural management practices on soil quality: A review of long-term experiments for Europe and China. Agric. Ecosyst. Environ. 2018, 265, 1-7. [CrossRef]

20. Statistic Canada 2016 Table 004-0243-Census of Agriculture, Farms Reporting Technologies in the Year Prior to the Census. Available online: http://www5statcangcca/cansim/a26?lang=eng\&retrLang=eng\&id= 0040243\&tabMode $=$ dataTable\&p1 $=-1 \&$ p2=11\&srchLan=-1 (accessed on 28 April 2020).

21. Mailvaganam, S. Statistical Summary of Ontario Agriculture: 2016. Data Ministry of Agriculture, Food and Rural Affaires (OMAFRA). Available online: http://wwwomafragovonca/english/stats/agriculture summaryhtm (accessed on 28 April 2020).

22. Vyn, T.J.; Raimbault, A. Long-term effect of Five tillage systems on corn response and soil structure. Agron. J. 1993, 85, 1074-1079. [CrossRef] 
23. Kludze, H.; Deen, B.; Weersink, A.; van Acker, R.; Janovicek, K.; De Laporte, A.; McDonald, I. Estimating sustainable crop residue removal rates and costs based on soil organic matter dynamics and rotational complexity. Biomass Bioenergy 2013, 56, 607-618. [CrossRef]

24. Larney, F.J.; Bremer, E.; Janzen, H.H.; Johnston, A.M.; Lindwall, C.W. Changes in total, mineralizable and light fraction soil organic matter with cropping and tillage intensities in semiarid southern Alberta, Canada. Soil Tillage Res. 1997, 42, 229-240. [CrossRef]

25. Campbell, C.; Zentner, R.; Selles, F.; Biederbeck, V.; McConkey, B.; Blomert, B.; Jefferson, P. Quantifying short-term effects of crop rotations on soil organic carbon in southwestern Saskatchewan. Can. J. Soil Sci. 2000, 80, 193-202.

26. Yang, X.M.; Kay, B.D. Rotation and tillage effects on soil organic carbon sequestration in a Typic Hapludalf in southern Ontario. Soil Tillage Res. 2001, 59, 107-114. [CrossRef]

27. Deen, W.; Kataki, P. Carbon sequestration in a long-term conventional versus conservation tillage experiment. Soil Tillage Res. 2003, 74, 143-150. [CrossRef]

28. Shrestha, B.; McConkey, B.; Smith, W.; Desjardins, R.; Campbell, C.; Grant, B.; Miller, P. Effects of crop rotation, crop type and tillage on soil organic carbon in a semiarid climate. Can. J. Soil Sci. 2013, 93, 137-146. [CrossRef]

29. Smith, E.G.; Janzen, H.H.; Scherloski, L.; Larney, F.J.; Ellert, B.H. Long-term (47 yr) effects of tillage and frequency of summerfallow on soil organic carbon in a Dark Brown Chernozem soil in western Canada. Can. J. Soil Sci. 2016, 96, 347-350. [CrossRef]

30. Jarecki, M.; Grant, B.; Smith, W.; Deen, B.; Drury, C.; VanderZaag, A.; Qian, B.; Yang, J.; Wagner-Riddle, C. Long-term trends in corn yields and soil carbon under diversified crop rotations. J. Environ. Qual. 2018, 47, 635-643. [CrossRef]

31. Soil Classification Working Group. The Canadian System of Soil Classification, 3rd ed.; Agriculture and Agri-Food Canada Publication 1646: Ottawa, ON, Canada, 1998; p. 187.

32. Hoffman, D.W.; Matthews, B.C.; Wicklund, R.E. Soil Survey of Wellington County Ontario; Report No.35; Ontario Soil Survey, Department of Agriculture and Ontario Department of Agriculture: Guelph, ON, Canada, 1963.

33. Environment Canada 2011 Canadian Climate Normals 1981-2010: Fergus Shand Dam Weather Station. Available online: http://climateweathergcca/climate_normals/index_ehtml (accessed on 28 April 2020).

34. Gaudin, A.C.; Tolhurst, T.N.; Ker, A.P.; Janovicek, K.; Tortora, C.; Martin, R.C.; Deen, W. Increasing crop diversity mitigates weather variations and improves yield stability. PLoS ONE 2015, 10, e0113261. [CrossRef]

35. Raimbault, B.; Vyn, T. Crop rotation and tillage effects on corn growth and soil structural stability. Agron. J. 1991, 83, 979-985. [CrossRef]

36. Wanniarachchi, S.; Voroney, R.; Vyn, T.; Beyaert, R.; MacKenzie, A. Tillage effects on the dynamics of total and corn-residue-derived soil organic matter in two southern Ontario soils. Can. J. Soil Sci. 1999, 79, 473-480. [CrossRef]

37. Wang, D.; Anderson, D.W. Direct measurement of organic carbon content in soils by the Leco CR-12 carbon analyzer Commun. Soil Sci. Plant Anal. 1998, 29, 15-21. [CrossRef]

38. R Development Core Team. R 2011 R: A Language and Environment for Statistical Computing; R Foundation for Statistical Computing: Vienna, Austria, 2011; Available online: http://www.R-project.org/ (accessed on 28 April 2020).

39. Angers, D.A.; Bolinder, M.A.; Carter, M.R.; Gregorich, E.G.; Drury, C.F.; Liang, B.C.; Voroney, R.P.; Simard, R.R.; Donald, R.G.; Beyaert, R.P.; et al. Impact of tillage practices on organic carbon and nitrogen storage in cool, humid soils of eastern Canada. Soil Tillage Res. 1997, 41, 191-201. [CrossRef]

40. Ramnarine, R.; Voroney, R.P.; Wagner-Riddle, C.; Dunfield, K.E. Conventional and no-tillage effects on the distribution of crop residues and light fraction organic matter. Soil Sci. Soc. Am. J. 2015, 79, 74-80. [CrossRef]

41. Karlen, D.L.; Cambardella, C.A.; Kovar, J.L.; Colvin, T.S. Soil quality response to long-term tillage and crop rotation practices. Soil Tillage Res. 2013, 133, 54-64. [CrossRef]

42. Yang, X.M.; Drury, C.F.; Wander, M.M.; Kay, B.D. Evaluating the effect of tillage on carbon sequestration using the minimum detectable difference concept. Pedosphere 2008, 18, 421-430. [CrossRef]

43. Ruis, S.J.; Blanco-Canqui, H.; Jasa, P.J.; Ferguson, R.B.; Slater, G. Can cover crop use allow increased levels of corn residue removal for biofuel in irrigated and rainfed systems? BioEnergy Res. 2017, 10, 992-1004. [CrossRef] 
44. McDaniel, M.D.; Grandy, S. Soil microbial biomass and function are altered by 12 years of crop rotation. Soil 2016, 2, 583-599. [CrossRef]

45. Franzluebbers, A.J.; Hons, F.M.; Zuberer, D.A. Seasonal changes in soil microbial biomass and mineralizable C and Nin wheat management systems. Soil Biol. Biochem. 1994, 26, 1469-1475. [CrossRef]

46. Agomoh, V.I.; Drury, C.F.; Phillips, L.A.; Reynolds, D.W.; Yang, X. Increasing crop diversity in wheat rotations increases yields but decreases soil health. Soil Sci. Soc. Am. J. 2020, 84, 170-181. [CrossRef]

47. Angers, D.A. Changes in soil aggregation and organic carbon under corn and alfalfa. Soil Sci. Soc. Am. J. 1992, 56, 1244-1249. [CrossRef]

48. Martel, Y.A.; Deschenes, J.M. Les effets de la mise en culture et de la prairies prolongée sur le carbone, l'azote et la structure de quelques sols du Québec. Can. J. Soil Sci. 1976, 56, 373-383. [CrossRef]

49. Kätterer, T.; Andrén, O.; Jansson, P.-E. Pedotransfer functions for estimating plant available water and bulk density in Swedish agricultural soils. Acta Agric. Scand. 2006, 56, 263-276.

50. Deng, F.; Minasny, B.; Knadel, M.; McBratney, A.; Heckrath, G.; Greve, M.H. Using vis-NIR spectroscopy for monitoring temporal changes in soil organic carbon. Soil Sci. 2013, 178, 389-399. [CrossRef]

51. Hancock, G.R.; Kunkel, V.; Wells, T.; Martinez, C. Soil organic carbon and soil erosion-understanding change at the large catchment scale. Geoderma 2019, 343, 60-71. [CrossRef]

52. Sorenson, P.T.; Small, C.; Tappert, M.C.; Quideau, S.A.; Drozdowski, B.; Underwood, A.; Janz, A. Monitoring organic carbon, total nitrogen, and $\mathrm{pH}$ for reclaimed soils using field reflectance spectroscopy. Can. J. Soil Sci. 2017, 97, 241-248. [CrossRef]

53. Hoffmann, M.; Jurisch, N.; Garcia Alba, J.; Albiac Borraz, E.; Schmidt, M.; Huth, V.; Rogasik, H.; Verch, G.; Sommer, M.; Augustin, J. Detecting small-scale spatial heterogeneity and temporal dynamics of soil organic carbon (SOC) stocks: A comparison between automatic chamber-derived C budgets and repeated soil inventories. Biogeosciences 2017, 14, 1003-1019. [CrossRef]

54. Bolinder, M.A.; Kätterer, T.; Andrén, O.; Parent, L.E.; Kirchman, H. Long-term soil organic carbon and nitrogen dynamics in forage-based crop rotations in northern Sweden $\left(63-64^{\circ} \mathrm{N}\right)$. Agric. Ecosyst. Environ. 2010, 132, 335-342. [CrossRef]

55. Lee, J.; Hopmans, J.W.; Rolston, D.E.; Baer, S.G.; Six, J. Determining soil carbon stock changes: Simple bulk density corrections fail. Agric. Ecosyst. Environ. 2009, 134, 251-256. [CrossRef] 